\title{
Gaps and solutions of HIV testing, care, and treatment in Iran during 2018-2019
}

\author{
SeyedAhmad SeyedAlinaghi ${ }^{1}$, Behnam Farhoudi², Parvin Afsar Kazerooni ${ }^{3}$, Mohammad Mehdi Gouya ${ }^{4}$, \\ Zeinab Najafi ${ }^{1}$, Ali-Akbar Haghdoost ${ }^{5}$, Hamid Sharifi ${ }^{6}$, Katayoun Tayeri ${ }^{1}$, Hengameh Namdari Tabar ${ }^{3}$, \\ Nima Ghalekhani ${ }^{6}$, Omid Dadras ${ }^{7}$
}

${ }^{1}$ Iranian Research Center for HIV/AIDS, Iranian Institute for Reduction of High Risk Behaviors, Tehran University of Medical Sciences, Tehran, Iran

${ }^{2}$ Social Determinants of Health Research Center, Amir-al-Momenin Hospital, Tehran Medical Sciences Branch, Islamic Azad University, Tehran, Iran

${ }^{3}$ HIV/AIDS Control Office, Center for Communicable Disease, Ministry of Health, Tehran, Iran

${ }^{4}$ Center for Communicable Disease Control, Ministry of Health \& Medical Education, Tehran, Iran

${ }^{5}$ Social Determinants of Health Research Center, Institute for Futures Studies in Health, Kerman University of Medical Sciences, Kerman, Iran

${ }^{6}$ HIV/STI Surveillance Research Center, and WHO Collaborating Center for HIV Surveillance, Institute for Futures Studies in Health, Kerman University of Medical Sciences, Kerman, Iran

${ }^{7}$ The Excellent Center for Dengue and Community Public Helath (EC for DACH), School of Public Health, Walailak University, Nakhon Si Thammarat, Thailand

\begin{abstract}
Introduction: Human immunodeficiency virus (HIV) test-treat-retain cascade analysis, is a model to identify gaps at every stage of service delivery, and formulate potential solutions to enhance coverage of these services, as we aimed to carry out in the present study.

Material and methods: In order to detect problems, develop solutions, and further prioritize them at different stages of HIV cascade, Fishbone analysis model (WHO 2018) was used. At first, an Excel file including 15 sheets was constructed, each sheet for a significant demographic data of sub-group covering all key populations. Within each sheet, cascade diagram for diagnostic services, connection to services, treatment, and suppression of viral load was demonstrated. Excel file was sent to 28 key persons. Participants were instructed to identify problems in each stage and list all probable reasons for every specific problem. These reasons were classified into six groups based on Fishbone model, including: 1) policies/guidelines; 2) service/program management; 3) human resources; 4) supplies; 5) services delivery methods; and 6) patient/ client-related factors. Subsequently, participants were instructed to propose their potential solutions to address these obstacles. Finally, four key informants prioritized the problems and suggested solutions.

Results: Analysis of the most important solutions (with 10-12 scores) proposed by key persons of the five groups, including the increase of society awareness, addressing the stigma of HIV disease in mass media, collaboration between politics and health parties to enhance society knowledge, expanding the treatment and counseling centers and facilities across the country, healthcare workers training to provide valid and reliable guidance and information to people who live with HIV, and refer them to designated centers for care, counseling, and treatment as well as appropriate patient detection, mapping procedure, and gathering precise statistics, and finally, employment of professional caregivers in counseling and testing centers.

Conclusions: Based on the identified gaps, innovative strategies to improve HIV testing and early case detection, particularly for key populations, are critical to reach the 90-90-90 target of the UNIAID.
\end{abstract}

HIV AIDS Rev 2021; 20, 4: 287-293

DOI: https://doi.org/10.5114/hivar.2021.111545

Key words: HIV testing, antiretroviral therapy, anti-HIV drugs, HIV infection diagnosis, HIV/AIDS testing.

Address for correspondence: Behnam Farhoudi, Social Determinants of Health Research Center, Amir-al-Momenin Hospital, Tehran Medical Sciences Branch, Islamic Azad University Tehran, Iran,

e-mail: b_farhoudi@yahoo.com
Article history:

Received: 02.02.2021

Received in revised form: 06.03.2021

Accepted: 17.03.2021

Available online: 30.11 .2021
International Journal of HIV-Related Problems

HIV \& AIDS R e vi e w 


\section{Introduction}

In response to The Joint United Nations Programme on HIV/AIDS (UNAIDS) new targets for human immunodeficiency virus (HIV) treatment beyond 2015, experts lunched new approach across the world to reach the goal of 90-90-90 by 2020 ; this means that by $2020,90 \%$ of all people living with HIV (PLHIV) would be expected to know their HIV status, $90 \%$ of all people diagnosed with HIV infection would receive sustained antiretroviral treatment (ART), and 90\% of all people receiving ART would have viral suppression [1]. HIV test-treat-retain cascade analysis is a model to identify gaps at any stage of service delivery, and formulate potential solutions to enhance the coverage of these services [2].

In 2018, according to national statistics, around 61,000 people were living with HIV in Iran. The annual HIV incidence was 0.05 for the general population. The percentage of adults aged 15-49 years living with HIV was $0.1 \%$, and the number of newly infected people was 4,400 . An estimated 2,600 people died from acquired immune deficiency syndrome (AIDS)-related illness. The number of AIDS-related deaths has increased by $8 \%$ since 2010 , from 2,400 deaths to 2,600 deaths. On the contrary, the number of new HIV infections decreased from 5,000 to 4,400 during the same period [3-5]. Early diagnosis and immediate initiation of ART are necessary to reduce the progression of HIV. Clinical studies have shown a substantial decrease in morbidity and mortality obtained by early diagnosis and treatment of HIV infection [6,7]. Moreover, a significant number of individuals who were unaware of their infection, usually remained undiagnosed until advanced stages of the disease when HIV-related morbidities started to appear [8-11].

Still, there are populations that are at a high-risk of HIV infection, and yet they are not sufficiently targeted with HIV prevention, care, and treatment services [12]. With continued advances in HIV treatment and increased knowledge concerning best practices for care, there is no justifiable reasons that PLHIV should receive suboptimal linkage to care and retention [13]. Expanding HIV testing centers could increase the availability of HIV test and consequently, decrease the number of undiagnosed people [14]. Therefore, it is essential to detect factors, which impede early HIV testing and diagnosis. Studies have shown certain barriers to global access to HIV testing, treatment, and care services as well as prevention of further transmission [15]. For instance, a study by Mercier et al. revealed that adults living with HIV who constantly struggle with taking life-long HIV medications, often lack social support in different aspects of their lives [16]. There are also some obstacles in receiving early and appropriate ART, such as long waiting times, transport costs, fears of privacy breaches, inappropriate staff attitudes, fragmented platforms of service delivery [17-21], high cost of medical care and drugs, lack of appropriate access to women's health services, difficulties with follow-up meetings due to long distances, family responsibilities, and other priorities in life. All these could enhance maladjustment and reduce patient's ability to access and receive medications as prescribed by healthcare provider [22].

In this qualitative study, we investigated the factors that obstruct HIV testing, treatment, and care using cascade analysis approach based on a conception of patients and healthcare providers in Iran. Findings could help healthcare system to improve early diagnosis and coverage of ART, therefore increase viral suppression and further reduce HIV transmission and related deaths. A study among people who inject drugs (PWID) in 2019 and another one among high-risk women affected by HIV in 2015, showed $71 \%$ and $70 \%$, respectively, of received HIV testing in the last 12 months. In 2015, $57 \%$ of prisoners had been ever tested for HIV. It seems that coverage of ART among PWID living with HIV needs to be improved. In 2019, 44\% of PWID living with HIV received ART in the past 12 months. Among 187,373 prisoners, 62,743 received opioid substitution therapy. In the same year, $54 \%$ of PWID received free syringes and needles in the past three months [23].

HIV test-treat-retain cascade analysis, is a model to identify gaps at every stage of service delivery as we aimed to carry out in the current study.

\section{Material and methods}

The research team carried out cascade analysis using WHO tool for HIV test-treat-retain cascade analysis [24]. A technical working group, including an epidemiologist, infectious diseases specialists, and experts from Ministry of Health $(\mathrm{MoH})$ conducted the study and performed the analysis. Technical working group received technical supports from a steering committee, including field experts, policymakers, key stakeholders, and people living with HIV.

\section{Instrument}

An Excel file with 15 sheets was designed. Each sheet indicated a specific sub-population, including children under 15 years old, male/female aged 15 years or older, male/female injection drug users (IDUs), sexually transmitted HIV patients, mother-to-child transmission patients, prisoners, female sex workers (FSW), amphetamine-type stimulants (ATS) users, men who have sex with men (MSM), and transgender people. Each sheet contained the test-treat-and-retain cascade diagram specifically for each sub-population (derived from National HIV Case Registry System and Spectrum). Excel file was introduced to technical working group and key informants. Participants were instructed to identify potential problems/gaps and explain the reasons, which might have caused these problems. The reasons were classified into six groups based on Fishbone analysis model, and included 1) policies/guidelines; 2) service/program management; 3) human resources; 4) supplies; 5) services delivery methods; and 6) patient/client-related factors. Subsequently, the participants suggested the possible solutions to address these issues. 


\section{Participants}

The current study consisted of 28 participants, including faculty members, stakeholders, researchers, PLWHIV and policy makers who received the Excel file by e-mail. They were instructed to provide their comments on any barrier and possible reasons and solutions for reaching the 90-90-90 goal.

\section{Analyses}

The comments were analyzed and categorized in an Excel file. The comments were sorted in tables. It should be noted that in order to facilitate the analysis, in each table, the items related to different demographic sub-groups were marked with different colors.

The presented problems and solutions for HIV testing, treatment, and care were reviewed, scored, and prioritized by a technical group consisting of two infectious diseases specialists and an epidemiologist (all working in the field of HIV in Iran), and a person living with HIV. Each item was scored from one to three (one: the lowest vs. three: the highest). Based on the comments of technical group, the sum of the lowest and the highest total scores were 4 and 12 points, respectively. The results were divided into three groups using Likert scale, and the final score was approximately equal to three. Therefore, scores from 10 to 12 were assumed as the first group with the highest priority, scores from 7 to 9 were considered as the second group with moderate priority, and scores from 4 to 6 represented the third group with the lowest priority.

\section{Ethical considerations}

Ethical necessities of the present study were reviewed and approved by the institutional review board (IRB) of Tehran University of Medical Science and Ministry of Health and Medical Education (MoH \& ME), with IR.TUMS.IKHC. REC.1399.529 ethics code. Moreover, the participants provided individual informed consent. Responses of the participants remained confidential, and only investigators affiliated with the project had access to them.

\section{Results}

The most important barriers to HIV testing, treatment, and care are listed in Table 1. As it has been shown, people infected through sexual contact were less likely to be identified and tested for HIV. Another problem was inadequate linkage between detected cases and triangular clinics. Triangular clinics are the core health service facilities, which provide HIV-related services, including ART, in Iran. Finally, the last but not least barrier was inadequate adherence to ART by the patients (Table 1 ).

Table 2 shows the suggested solutions for prevention and addressing the problems of testing, treatment, and care for HIV. The suggested solutions of effective approaches to remove the barriers and address the problems of HIV testing, care, and treatment were as follow: the increase of social awareness through mass media, movies, and serials in both audio- and video-type products; applying innovative ways for information distribution; referring high-risk populations for testing and screening by trained health professionals; implementing a mapping project for key population and utilization of its' results in revising preventive programs; reduction of discrimination and stigma, and expansion of HIV testing; securing the capacities required for successful implementation of programs, establishing necessary facilities and ensuring the access to counseling and testing centers for viral load check (Table 2).

\section{Discussion}

The main problems regarding HIV testing, care, and treatment emphasized by the technical team of present study, included underrepresentation of those infected through sexual routes, which represent a large gap between estimated and registered PLHIV cases (inadequate screening), followed by weakness in linkage to counseling centers and inadequate adherence to treatment. The findings suggest the following solutions: 1) boosting existing programs, including cooperation with religious leaders; 2) consideration of new programs, such as self-HIV testing, house-to-house HIV testing, community antiretroviral therapy (ART) provision and teach-test-treat-link strategy; and 3) reorganizing and

Table 1. Prioritization of the problems for HIV testing, treatment, and care based on the scores of four key people (three specialists and one PLHIV)

\begin{tabular}{l|c|c}
\hline Stages of HIV cascade & Group one (points 10-12): highest priority & Group two (points 7-9): medium priority \\
\hline Diagnosis & $\begin{array}{c}\text { Those infected by HIV through sexual routes } \\
\text { are less likely to be identified }\end{array}$ & $\begin{array}{c}\text { Inaccurate estimate of the number of PLHIV } \\
\text { and its' changes over the past years }\end{array}$ \\
\hline Treatment and care & $\begin{array}{c}\text { A large gap between estimated and registered } \\
\text { cases (inadequate screening) }\end{array}$ & Low HIV care coverage \\
\hline Viral suppression & Weakness in linkage to triangular clinics & Insufficient coverage of viral load test \\
\cline { 2 - 3 } & Inadequate adherence to ART & $\begin{array}{c}\text { Non-suppressed viral load in some sub-group } \\
\text { population on ART }\end{array}$ \\
\cline { 2 - 3 } & & \begin{tabular}{c} 
Inadequate coverage of ART \\
\hline
\end{tabular}
\end{tabular}


Table 2. Prioritization of the solutions for HIV testing, treatment, and care cascade based on the scores of four key people

\begin{tabular}{|c|c|c|}
\hline $\begin{array}{l}\text { Group one (10-12): } \\
\text { highest priority }\end{array}$ & $\begin{array}{l}\text { Group two }(7-9): \\
\text { medium priority }\end{array}$ & $\begin{array}{l}\text { Group three (4-6): } \\
\text { lowest priority }\end{array}$ \\
\hline $\begin{array}{l}\text { High-level of advocacy in political } \\
\text { and cultural authorities }\end{array}$ & Performing hidden population studies & $\begin{array}{c}\text { Encouraging people through education } \\
\text { and reduce stigma related to visiting } \\
\text { VCT centers }\end{array}$ \\
\hline $\begin{array}{l}\text { Appropriate referral of cases with positive } \\
\text { HIV screening test to VCT centers }\end{array}$ & $\begin{array}{l}\text { Accurate data collection to ensure its' } \\
\text { validity and reliability }\end{array}$ & $\begin{array}{l}\text { Using the capacity of private sector } \\
\text { (laboratories) to carry out viral load } \\
\text { and drug resistance testing }\end{array}$ \\
\hline $\begin{array}{l}\text { Training key populations using peers } \\
\text { and self-introduction for testing }\end{array}$ & $\begin{array}{l}\text { Comprehensive data collection from } \\
\text { all centers (private sector, hospitals, } \\
\text { offices, and laboratory network } \\
\text { in the country) }\end{array}$ & $\begin{array}{c}\text { Monitoring distribution for viral } \\
\text { load kits, and ensuring the quality } \\
\text { of sampling and transfer to laboratory } \\
\text { at a university level }\end{array}$ \\
\hline $\begin{array}{c}\text { Increase society awareness through mass } \\
\text { media, movies, and serials in both audio- } \\
\text { and video-type products, and applying } \\
\text { an innovative ways of information } \\
\text { distribution }\end{array}$ & $\begin{array}{l}\text { Expanding testing facilities, kits' } \\
\text { providing, ensuring test quality, } \\
\text { and facilitating testing in all } \\
\text { laboratories and clinics }\end{array}$ & $\begin{array}{l}\text { Engaging nutrition specialists } \\
\text { at counseling centers to improve } \\
\text { patients' nutrition }\end{array}$ \\
\hline $\begin{array}{c}\text { Improving screening program by matched } \\
\text { groups (through retraining and briefing } \\
\text { sessions) }\end{array}$ & $\begin{array}{c}\text { Establishing well-equipped laboratories } \\
\text { in related academic institutions, } \\
\text { such as medical universities }\end{array}$ & $\begin{array}{l}\text { Hold campaigns in related } \\
\text { departments of public hospitals } \\
\text { to increase HIV awareness }\end{array}$ \\
\hline $\begin{array}{l}\text { Elimination of political barriers } \\
\text { and cultural sensitivities }\end{array}$ & $\begin{array}{l}\text { Encouraging healthcare providers to } \\
\text { perform diagnostic tests and increase } \\
\text { the use of PITC }\end{array}$ & $\begin{array}{l}\text { Engaging sports medicine specialists } \\
\text { in patients' care }\end{array}$ \\
\hline $\begin{array}{l}\text { Implementing a mapping project and use } \\
\text { its' results in formulating future plans }\end{array}$ & Recruiting international experts & Treatment approach modification \\
\hline $\begin{array}{l}\text { Modifying death registration system to } \\
\text { ensure validity of HIV-related deaths data }\end{array}$ & $\begin{array}{l}\text { Coordination between organizations } \\
\text { and program implementing parties } \\
\text { in delivering joint or similar programs }\end{array}$ & $\begin{array}{l}\text { Simultaneous treatment of psychiatric } \\
\text { disorders }\end{array}$ \\
\hline $\begin{array}{l}\text { Reducing discrimination and stigma } \\
\text { of HIV testing }\end{array}$ & $\begin{array}{l}\text { Screening program considered } \\
\text { as 'incentive' }\end{array}$ & - \\
\hline $\begin{array}{c}\text { Appropriate and adequate patients' } \\
\text { education and motivation by emphasis } \\
\text { on having a normal life and given } \\
\text { a successful treatment }\end{array}$ & Expanding TB screening programs & - \\
\hline $\begin{array}{l}\text { Establishing necessary facilities } \\
\text { and ensuring access to triangular clinics } \\
\text { for viral load checking }\end{array}$ & $\begin{array}{l}\text { Identification of poor people } \\
\text { and providing them with services }\end{array}$ & - \\
\hline- & $\begin{array}{l}\text { Providing hepatitis treatment } \\
\text { at facilities along with HIV treatment }\end{array}$ & - \\
\hline $\begin{array}{l}\text { Adequate case detection by outreach } \\
\text { teams and mobile clinics }\end{array}$ & $\begin{array}{l}\text { Developing supportive plans } \\
\text { to encourage patients' adherence } \\
\text { to treatment }\end{array}$ & - \\
\hline $\begin{array}{l}\text { Conducting studies to assess status } \\
\text { and explore possible causes of failure } \\
\text { to absorb identified cases at VCTs }\end{array}$ & $\begin{array}{l}\text { Administrating of low burden pills } \\
\text { with longest half-life }\end{array}$ & - \\
\hline $\begin{array}{l}\text { Training sessions and individual } \\
\text { counseling during the course } \\
\text { of treatment }\end{array}$ & $\begin{array}{l}\text { Conducting qualitative or quantitative } \\
\text { studies to evaluate patients' beliefs } \\
\text { about ART and their perceived barriers } \\
\text { of survival following treatment }\end{array}$ & - \\
\hline $\begin{array}{l}\text { Promoting interactions and cooperation } \\
\text { between different organizational levels } \\
\text { and policymakers }\end{array}$ & $\begin{array}{l}\text { Conducting studies with new } \\
\text { approaches/ improving data collection, } \\
\text { especially in planning/ screening } \\
\text { programs to obtain comprehensive data }\end{array}$ & - \\
\hline
\end{tabular}


Table 2. Cd.

\begin{tabular}{|c|c|c|}
\hline $\begin{array}{l}\text { Group one (10-12): } \\
\text { highest priority }\end{array}$ & $\begin{array}{l}\text { Group two (7-9): } \\
\text { medium priority }\end{array}$ & $\begin{array}{l}\text { Group three (4-6): } \\
\text { lowest priority }\end{array}$ \\
\hline $\begin{array}{l}\text { Providing mobile services to patients who } \\
\text { are unable to visit/ connect centers }\end{array}$ & $\begin{array}{l}\text { Ethical considerations to prevent } \\
\text { discrimination by employees }\end{array}$ & - \\
\hline $\begin{array}{l}\text { Developing initiatives and plans to ensure } \\
\text { availability and feasibility of HIV test, at } \\
\text { least in key populations }\end{array}$ & $\begin{array}{l}\text { Designing and implementing } \\
\text { an integrated registration system } \\
\text { for AIDS, with respect to ethical } \\
\text { considerations, to facilitate sharing } \\
\text { of information at various centers }\end{array}$ & - \\
\hline $\begin{array}{l}\text { Recruiting qualified staff at counseling } \\
\text { centers, especially key people such as } \\
\text { physicians and psychologists }\end{array}$ & $\begin{array}{l}\text { Utilizing the knowledge and expertise } \\
\text { of outstanding and successful people } \\
\text { in the field }\end{array}$ & - \\
\hline Regular training of counseling staff & Insurance coverage for viral load tests & - \\
\hline Implementing instructions for LTFU $^{2}$ & $\begin{array}{l}\text { Conducting quantitative or qualitative } \\
\text { studies to assess patients' beliefs about } \\
\text { protective effects of treatment on } \\
\text { possibility of HIV transmission, } \\
\text { and study of risk behaviors modification } \\
\text { before and after drug therapy }\end{array}$ & - \\
\hline $\begin{array}{c}\text { Ensuring timely distribution of viral } \\
\text { load determination kits by appropriate } \\
\text { planning }\end{array}$ & $\begin{array}{c}\text { Consideration of pharmacy-based HIV } \\
\text { self-testing }\end{array}$ & - \\
\hline $\begin{array}{c}\text { Adding mobile units to fixed sites } \\
\text { (counseling centers and women's centers) }\end{array}$ & $\begin{array}{l}\text { Establishing and expanding special } \\
\text { centers for care and treatment } \\
\text { of sexually transmitted infections, } \\
\text { allowing access to HIV testing } \\
\text { in these centers }\end{array}$ & - \\
\hline $\begin{array}{c}\text { Drop-in center (DIC) instead of covering } \\
\text { areas are required to identify and cover } \\
\text { newly infected cases }\end{array}$ & - & - \\
\hline $\begin{array}{l}\text { Timely delivery of requested drugs and } \\
\text { monitoring drug complications }\end{array}$ & - & - \\
\hline $\begin{array}{c}\text { Discussion with domestic and foreign } \\
\text { pharmaceutical companies }\end{array}$ & - & - \\
\hline $\begin{array}{c}\text { Identification of inefficient service } \\
\text { providers }\end{array}$ & - & - \\
\hline
\end{tabular}

${ }^{1}$ Provider-initiated testing and counseling. ${ }^{2}$ Lost to follow-up

integrating services, such as ART, in health posts and private clinics as well as incorporating HIV care services into mental health and other non-communicable diseases services. More robust monitoring from a facility to global levels and implementation of established and emerging interventions are needed at each step of the cascade, to enhance HIV diagnosis, linkage to care and retention, ART use and adherence, and ultimately, reduction of viral load, improvement of clinical outcomes, and decreasing HIV transmission [25, 26]. Early diagnosis could be improved through self- and homebased HIV testing [27], ART linkage and retention through community ART groups as well as integration and collaboration with religious leaders $[28,29]$.

In 1992, according to WHO's guideline, first report was developed on environmental impact assessment (EIA).
The purpose of the cascade analysis in HIV research was to determine a condition in each country, existing gaps in achieving the 90-90-90 target, causes of these gaps, and what could be done to eliminate them [30]. Accordingly, in the present study, we evaluated the obstacles and potential solutions regarding adequate delivery of HIV-related services in Iran at three stages, including diagnosis, treatment/care, and viral suppression, despite possible multiple sub-steps in each stage. The cascade could be separately drawn for important sub-groups, such as children under the age of 15 , or other key populations. It could also represent a specific situation for a country or province, or even a health facility. This program has the ability to compare between sub-groups and provinces. The cascade program could be run in a software designed specifically for PLHIV, 
and all necessary information could be extracted from the software [31].

In the cascade analysis, typical ways of data collection are to browse resources and interview with key informants. In various sub-groups, such as people who inject drugs, more research had to be done to acquire sufficient information. However, in some sub-groups, such as transgenders, there is lack of accurate information [32].

A substantial knowledge for HIV treatment in cascade could be obtained from a registry data of HIV patients. The trajectory trend in Iran estimated a number of PLHIV to be around 59,000 in 2018, while there were only about 23,000 (39\%) diagnosed and registered HIV patients in national HIV registry system at the end that year. According to the same case registry system, 13,857 have visited at least once during 2018, and 12,345 (21\%) people were under ART at the end of that year. Furthermore, there were also 7,465 (85\%) PLHIV with suppressed viral load out of 8,808 who tested for HIV viral load during 2018 [1, 32].

People injecting drugs are one sub-groups of PLHIV that causes huge discrepancies in recorded and real statistics. The problem is the difference between estimation of spectrum, and the recorded data in case registry system. Based on the current HIV registry system in Iran, about 15,000 people with HIV have ever used drug injection, while the number seems to be higher than the given data. This discrepancy may be due to the fact that anyone with history of drug injection is considered infected through drug injection, but the spectrum estimates current drug injectors who live with HIV [33]. Another knowledge gap is the underrepresentation of sexually infected individuals in national statistics due to stigma behind extramarital sex. However, the adherence to ART appeared to be better in this group compared to that of the injecting drug users and therefore, the treatment response is more prominent [34].

The National HIV Case Registry System allows us to compare the annual survival rate between different treatment groups in different years. The causes for treatment discontinuation include death, lack of access to drugs, drug resistance, migration and other causes. In recent years, the HIV-related deaths have been declined, and non-compliance has been the main cause of discontinuation of treatment. In a study on 3,586 HIV patients over a median follow-up of 45 weeks, 312 patients (36.2\%) discontinued therapy, amongst them 182 (21.1\%) discontinued due to toxicity and $44(5.1 \%)$ due to failure [35].

The National HIV Case Registry System has several shortcomings in extracting data from HIV-related health facilities. Moreover, due to ineffective data collection, there is possibility of case duplication in statistics, and this should be corrected in data analysis in field research. Official statistics that represent the number of HIV tests were performed until 2018 in public health centers across the country, but this statistics had two difficulties; first, the number of reported cases did not indicate the number of people who actually did HIV test, but reflect the frequency of HIV test [37]. Second, the number of HIV-positive tests was not proportional to the size of population, but rather based on location of testing center (e.g., DIC). Therefore, essential measures should be implemented in order to improve the electronic medical record and future endeavor should be directed toward improving this system through the linkage to different platforms, data registries using internet and wireless connection as well as web-based facilities, in order to improve data registry and availability for HIV testing, care, and treatment [38].

There were some limitations of the present study. First, the number of PLHIV was estimated by statistical modeling, which subjected to model assumptions and uncertainties. Second limitation was related to adherence to ART and viral load suppression, which were not measured or reported systematically for people receiving ART. Therefore, there were not able to be evaluated. Third, we used data for all registered HIV cases until 2018 and analyzed overall cascade, which may not reflect the cascade of recently diagnosed patients or sub-groups defined by demographic characteristics or key populations.

\section{Conclusions}

The most important solutions for shortcoming in HIV testing, treatment, and care, were determined based on the scores given by key informants in the present study (with 10-12 scores). These solutions could be categorized into five groups, including enhancing the awareness, and reducing the stigma and socio-cultural sensitivity through mass media; training healthcare workers to provide correct guidance and communicate valid information for PLHIV, referring them to designated centers for care, counseling, and treatment; effective collaboration between political and health parties to increase social awareness and expand the treatment and counseling centers and facilities; appropriate case detection, mapping procedures, and gathering precise statistics; and finally, recruiting qualified caregivers in counseling and testing centers.

\section{Acknowledgements}

We would like to thank the staff in AIDS control office for their kind help and precious efforts. The authors also thank the UNAIDS and the World Health Organization office in Iran, especially Dr. Fardad Doroudi, Dr. Alireza Vasigh, and Dr. Omid Zamani.

\section{Acknowledgements}

This study was supported by the World Health Organization office in Iran.

\section{Conflict of interest}

The authors declare no conflict of interest.

\section{References}

1. http://www.unaids.org/en/resources/909090.

2. Consortium WTS. Timing of initiation of antiretroviral therapy in AIDS-free HIV-1-infected patients: a collaborative analysis of 18 HIV cohort studies. Lancet 2009; 373: 1352-1363. 
3. Sardashti S, Samaei M, Firouzeh MM, Mirshahvalad SA, Pahlaviani FG, SeyedAlinaghi S. Early initiation of antiretroviral treatment: Challenges in the Middle East and North Africa. World J Virol 2015; 4: 134-141.

4. Center for Communicable Diseases Control, Ministry of Health and Medical Education. Latest statistics on HIV infection in Islamic Republic of Iran, April to June 2017; 2018.

5. Joulaei H, Motazedian N. Primary health care strategic key to control HIV/AIDS in Iran. Iran J Public Health 2013; 42: 540-541.

6. Palella Jr FJ, Delaney KM, Moorman AC, et al. Declining morbidity and mortality among patients with advanced human immunodeficiency virus infection. N Engl J Med 1998; 338: 853-860.

7. Kitahata MM, Gange SJ, Abraham AG, et al. Effect of early versus deferred antiretroviral therapy for HIV on survival. N Engl J Med 2009; 360: 1815-1826.

8. Castilla J, Sobrino P, de la Fuente L, Noguer I, Guerra L, Parras F. Late diagnosis of HIV infection in the era of highly active antiretroviral therapy: consequences for AIDS incidence. AIDS 2002; 16: 1945-1951.

9. Easterbrook PJ, Yu LM, Goetghebeur E, Boag F, McLean K, Gazzard B. Ten-year trends in CD4 cell counts at HIV and AIDS diagnosis in a London HIV clinic. AIDS 2000; 14: 561-571.

10. Sabin CA, Smith CJ, Gumley H, et al. Late presenters in the era of highly active antiretroviral therapy: uptake of and responses to antiretroviral therapy. AIDS 2004; 18: 2145-2151.

11. Sudarshi D, Pao D, Murphy G, Parry J, Dean G, Fisher M. Missed opportunities for diagnosing primary HIV infection. Sex Trans Infect 2008; 84: 14-16.

12. Bajunirwe F, Tumwebaze F, Abongomera G, Akakimpa D, Kityo C, Mugyenyi PN. Identification of gaps for implementation science in the HIV prevention, care and treatment cascade; a qualitative study in 19 districts in Uganda. BMC Res Notes 2016; 9: 217.

13. Kay ES, Batey DS, Mugavero MJ. The HIV treatment cascade and care continuum: updates, goals, and recommendations for the future. AIDS Res Ther 2016; 13: 35

14. Hamers F, Devaux I, Alix J, Nardone A. HIV/AIDS in Europe: trends and EU-wide priorities. Euro Surveill 2006; 11: E061123.1.

15. Moradi G, Mohraz M, Gouya M, et al. Problems of providing services to people affected by HIV/AIDS: service providers and recipients perspectives. East Mediterr Health J 2015; 21: 20-28.

16. Mercier DA. A mixed methods study of perceived social support based on the medical outcomes study social support survey in adults with repeated challenges with HIV medication adherence. Columbia: University of Missouri; 2016.

17. Mills EJ, Nachega JB, Bangsberg DR, et al. Adherence to HAART: a systematic review of developed and developing nation patientreported barriers and facilitators. PLoS Med 2006; 3: e438.

18. Haas AD, Msukwa MT, Egger M, et al. Adherence to antiretroviral therapy during and after pregnancy: cohort study on women receiving care in Malawi's option B+ program. Clin Infect Dis 2016; 63: $1227-1235$

19. Posse M, Meheus F, Van Asten H, Van Der Ven A, Baltussen R. Barriers to access to antiretroviral treatment in developing countries: a review. Trop Med Int Health 2008; 13: 904-913.

20. Kagee A, Remien R, Berkman A, Hoffman S, Campos L, Swartz L. Structural barriers to ART adherence in Southern Africa: challenges and potential ways forward. Global Public Health 2011; 6: 83-97.

21. Daryazadeh S. Investigation of adherence and process of anti-retroviral therapy in patients referred to Isfahan Behavioral Consultation Center during ten years. Razi Journal of Medical Sciences 2014; 21 62-70.

22. Mukherjee JS, Ivers L, Leandre F, Farmer P, Behforouz H. Antiretroviral therapy in resource-poor settings: decreasing barriers to access and promoting adherence. J Acquir Immune Defic Syndr 2006; 43 S123-S126.

23. Global AIDS Monitoring. Country progress report - Iran 2020.
24. Organization WH. HIV test-treat-retain cascade analysis: guide and tools; 2014.

25. Khalili H, Rohani R, Seyedalinaghi S, Hajiabdolbaghi M, DashtiKhavidaki S, Talasaz AH. Adherence to antiretroviral therapy among Iranian HIV/AIDS patients. Curr Clin Pharmacol 2012; 7 : 111-115.

26. Kilmarx PH, Mutasa-Apollo T. Patching a leaky pipe: the cascade of HIV care. Curr Opin HIV AIDS 2013; 8: 59-64.

27. Niakan S, Mehraeen E, Noori T, Gozali E. Web and mobile based HIV prevention and intervention programs pros and cons - a review. Stud Health Technol Inform 2017; 236: 319-327.

28. Mehraeen E, Safdari R, SeyedAlinaghi S, Mohammadzadeh N Exploring and prioritization of mobile-based self-management strategies for HIV care. Infectious Disorders - Drug Targets 2019; 19: 288-296.

29. Gesesew H, Ward P, Woldemichael K, Mwanri L. Improving the UNAIDS 90-90-90 treatment targets: solutions suggested from a qualitative study of HIV patients, community advocates, health workers and program managers in Jimma, Southwest Ethiopia. Int J Environ Res Public Health 2020; 17: 378.

30. Maman D, Chilima B, Masiku C, et al. Closer to 90-90-90. The cascade of care after 10 years of ART scale-up in rural Malawi: a population study. J Int AIDS Soc 2016; 19: 20673.

31. Mazhnaya A, Marcus R, Bojko MJ, et al. Opioid agonist treatment and improved outcomes at each stage of the HIV treatment cascade in people who inject drugs in Ukraine. J Acquir Immune Defic Syndr 2018; 79: 288-295.

32. http://www.unodc.org/postungass2016/.

33. Baesi K, Moallemi S, Farrokhi M, Alinaghi SAS, Truong HHM. Subtype classification of Iranian HIV-1 sequences registered in the HIV databases, 2006-2013. PLoS One 2014; 9: e105098.

34. Zadeh AOT, SeyedAlinaghi S, Hassanzad FF, et al. Prevalence of HIV infection and the correlates among homeless in Tehran, Iran. Asian Pac J Trop Biomed 2014; 4: 65-68.

35. d'Arminio Monforte A, Lepri AC, Rezza G, et al. Insights into the reasons for discontinuation of the first highly active antiretroviral therapy (HAART) regimen in a cohort of antiretroviral naive patients. AIDS 2000; 14: 499-507.

36. Siika AM, Rotich JK, Simiyu CJ, et al. An electronic medical record system for ambulatory care of HIV-infected patients in Kenya. Int J Med Inform 2005; 74: 345-355.

37. Ghalehkhani N, Farhoudi B, Gouya MM, et al. The HIV treatment cascade in people living with HIV in Iran in 2014: mixed-method study to measure losses and reasons. Int J STD AIDS 2019; 30: 1257-1264.

38. SeyedAlinaghi S, Taj L, Mazaheri-Tehrani E, et al. HIV in Iran: onset, responses, and future directions. AIDS 2021; 35: 529-542. 